\title{
Metabolites and Immune Variables Associated with Somatic Cell Counts of Primiparous Dairy Cows
}

\author{
A.-K. Nyman, ${ }^{\star} \dagger^{1}$ U. Emanuelson,‡ K. Holtenius,§ K. L. Ingvartsen,\# T. Larsen,\# and K. Persson Waller* $¥$ \\ ${ }^{*}$ Department of Animal Health and Antimicrobial Strategies, National Veterinary Institute, SE-751 89 Uppsala, Sweden \\ †Swedish Dairy Association, PO Box 7019, SE-750 07 Uppsala, Sweden \\ łDepartment of Clinical Sciences, Swedish University of Agricultural Sciences, PO Box 7054, SE-750 07 Uppsala, Sweden \\ $\S$ Department of Animal Nutrition and Management, Kungsängen Research Centre, Swedish University of Agricultural Sciences, \\ Uppsala SE-753 23, Sweden \\ \#Department of Animal Health, Welfare and Nutrition, Faculty of Agricultural Sciences, Aarhus University, PO Box 50, DK-8830 Tjele, Denmark
}

\begin{abstract}
The main objective of this study was to investigate associations between serum concentrations of several blood variables related to metabolic and immunological status around calving, and udder health measured as milk somatic cell counts (SCC), Box-Cox transformed to bcSCC, at first test-milking in 287 primiparous cows in 20 Swedish dairy herds. Possible systematic effects of breed and age at calving on blood profiles were also investigated. Ordinary linear regression models, with robust standard errors and adjusting for clustering within herds, were used to investigate associations between blood variables and bcSCC. Hierarchical linear regression models, with herd as random factor, were used to investigate systematic effects on blood variables. The results showed that greater concentrations of $\beta$-hydroxybutyrate (BHBA) and glucose before calving were associated with lesser bcSCC at first test-milking, whereas greater concentrations of nonesterified fatty acids (NEFA) before calving and greater delta NEFA (describing the difference in concentrations before and after calving) were associated with greater bcSCC at first test-milking. In addition, greater $\alpha$-tocopherol concentrations in the period -5 to $+5 \mathrm{~d}$ relative to calving were associated with lesser bcSCC at first test-milking, whereas greater concentrations of collectin of $43 \mathrm{kDa}$ (CL-43) postpartum (1 to $21 \mathrm{~d}$ after calving) were associated with greater bcSCC. Postpartum concentrations of conglutinin and haptoglobin were also associated with bcSCC, but not independently of each other. Moreover, significant breed differences were observed for insulin, urea nitrogen, conglutinin, cholesterol, NEFA, and CL43 , the latter 3 as an interaction with period. Overall, cows of the Swedish Red breed had greater concentra-
\end{abstract}

Received December 21, 2007.

Accepted May 1, 2008.

${ }^{1}$ Corresponding author: ann.nyman@sva.se tions of insulin, cholesterol, urea nitrogen, and conglutinin, and lesser concentrations of NEFA and CL-43 than cows of the Swedish Holstein breed. Age at calving as main effect was significantly associated with BHBA, glucose, insulin, NEFA, urea nitrogen, and conglutinin. Heifers calving at $>27$ mo of age had greater BHBA and NEFA values, and lesser glucose, insulin, and urea nitrogen values compared with heifers calving at $<27$ mo. Heifers calving at an age $<25$ mo had greater conglutinin and urea nitrogen values, and lesser NEFA values compared with heifers calving at $>25$ mo. The results show that there are several associations among metabolites, immunological variables, and udder health of primiparous cows, but also that these variables vary between breeds and between cows of different age at first calving.

Key words: primiparous dairy cow, somatic cell count, immune variable, metabolite

\section{INTRODUCTION}

Most diseases of dairy cows occur in the periparturient period and in early lactation. In this period cows experience immense physiological changes preparing the animal for calving and the onset of lactation. Primiparous cows have lesser milk yield compared with older cows, but may still be in a poorer energy status in the period around calving, although results vary (Cavestany et al., 2005; Wathes et al., 2007). In general, primiparous cows have a lower incidence of mastitis than older cows, but in early lactation they have as great, or greater, prevalence of mastitis than older cows (Miltenburg et al., 1996; Barkema et al., 1998; Nyman et al., 2007), possibly indicating a lesser ability to cope with stressors occurring during the periparturient period. Moreover, several important immune functions are impaired around calving (Kehrli et al., 1989; Sordillo et al., 1991), increasing the susceptibility to infections. 
As a response to the large nutrient demand during the periparturient period and in early lactation, nutrients are mobilized from tissue reserves. The metabolic changes can be measured as marked alterations in blood concentrations of a large number of hormones and metabolites (Ingvartsen and Friggens, 2005). The large need of glucose for milk lactose production causes a decrease in blood glucose and insulin concentration. The lesser insulin concentration shifts the balance between lipogenesis and lipolysis causing mobilization of fat from the adipose tissue resulting in a rise in NEFA in plasma, whereas the increased ketogenesis in hepatic tissue increases the concentration of ketone bodies [e.g., $\beta$-OH-butyrate (BHBA)] in blood. Elevated NEFA and BHBA concentrations, and decreased glucose and insulin concentrations, are indications of negative energy balance (NEB; van Knegsel et al., 2005). Cholesterol and urea nitrogen are also important metabolites associated with transport of triglycerides from the liver and protein metabolism, respectively. The blood concentrations of both these metabolites decrease at calving (Cavestany et al., 2005). Few studies have, however, specifically investigated metabolic profiles of primiparous cows (Wathes et al., 2007).

The relationship between metabolic changes in early lactation and immune functions is complex (Ingvartsen et al., 2003) and not yet well understood. Greater NEFA concentrations have, for instance, been associated with an increased lipid infiltration in the liver, possibly influencing the hepatic production of proteins involved in inflammatory and immune responses. Greater concentrations of both NEFA and BHBA have been associated with impaired immune functions and mastitis in dairy cows as reviewed, for example, by Burvenich et al. (2007). Moreover, previous studies have shown a relationship between less milk urea nitrogen concentrations and an increased risk of udder disorders (Bareille et al., 2000; unpublished data). It is not known if there is a similar relationship between blood urea nitrogen and udder health, but it is likely because urea nitrogen concentrations in milk and blood are closely associated (Broderick and Clayton, 1997; Wang et al., 2007). In line with this, Ohtsuka et al. (2006) found lesser blood urea nitrogen concentrations, as well as lesser serum total cholesterol concentrations, in cows from 2 herds with mastitis problems compared with cows from a healthy control herd.

Other nutrients of importance for the immune system and udder health of dairy cows in the periparturient period are vitamin $\mathrm{E}$ and selenium. Supplementation with vitamin $\mathrm{E}$ and selenium during the dry period is associated with enhanced immune functions (Hogan et al., 1992; Cebra et al., 2003), and some have found beneficial effects of vitamin $\mathrm{E}$ and selenium supplemen- tation on udder health (Smith et al., 1984; Weiss et al., 1990).

Besides being important in metabolism, the liver is also the main site for production of proteins important for the acute phase response and innate immune system, such as haptoglobin and collectins. The acute phase protein haptoglobin has broad anti-inflammatory activities, functions as a bacteriostatic agent, and is involved in angiogenesis (Murata et al., 2004). Collectins, for example, conglutinin and collectin of $43 \mathrm{kDa}$ (CL-43) are humoral molecules of the innate immune system that recognize pathogen-associated molecular patterns. They have a key role in the first line of defense against invading microorganisms because they are able to aggregate pathogens, neutralize viruses, activate phagocytes, and promote phagocytosis (Dec and Wernicki, 2006). The presence of haptoglobin and collectins in early lactation and their importance for udder health have not been described in detail.

Genetic predisposition is known to affect the udder health, and breed differences have been observed. In Sweden, for instance, difference in udder health is found between the 2 main dairy breeds Swedish Red (SR) and Swedish Holstein (SH; Swedish Dairy Association, 2006). In 2005/2006 the average incidence of CM was 13.8 cases/100 lactations for cows of the SR-breed and 17.4 cases/100 lactations for cows of the SH-breed, and such a difference has existed for the last decade, as well as a difference in prevalence and incidence of infectious mastitis based on changes in SCC between test milkings (Swedish Dairy Association, 2006). The reason for the difference in udder health between the 2 breeds is not known, but differences in physiology, immune status, or both may be of importance. Breed differences have also been observed for blood metabolites, both in Sweden (Odensten et al., 2007) and elsewhere (Rastani et al., 2001; Ingvartsen and Friggens, 2005; French, 2006). Breed differences in immunological variables have to our knowledge not been extensively investigated, though there is plentiful evidence of a genetic influence on immune functions as reviewed by Mallard et al. (1998).

A factor also shown to be of importance for the udder health of primiparous cows is age at first calving. Waage et al. (1998) found an increased risk of mastitis with increased age at first calving. A similar association between age at calving and ketosis has also been observed (van Dam et al., 1988). It is thus possible that metabolites and immune variables may differ between primiparous cows of different age at first calving.

Information about metabolic and immunological status of primiparous cows in early lactation, and their association with udder health, is scarce. The main aim of this study was therefore to investigate associations 
among concentrations of several blood variables related to metabolism and immune response around calving in primiparous cows, and udder health measured as SCC at first test-milking. We also wanted to identify possible systematic effects of breed (SR and SH breed) and age at calving on these blood variables.

\section{MATERIALS AND METHODS}

\section{Herds}

Herds eligible for selection were 78 herds that already had accepted to participate in a study of risk factors associated with udder health of primiparous cows (unpublished data). Briefly, herds had to be enrolled in the official Swedish milk recording scheme (SOMRS) and the animal disease recording scheme (SADRS), have a herd size $\geq 80$ cows, a bulk-milk SCC (BMSCC) below the Swedish average for free-stall herds ( $\leq 192,000$ cells/ $\mathrm{mL}$ ), a milk production above the Swedish average for free-stall herds ( $>8,900 \mathrm{~kg}$ of milk), and free-stall housing. The herds with the greatest expected number of primiparous cows calving during the first 4 mo (October to January) of the study period (October 1, 2005 to March 31, 2006) were contacted again and asked to participate also in the present study. When 20 farmers had accepted, no more farmers were contacted. The sample size was set to 20 for practical and economic reasons. One farm dropped out after half the study period due to lack of time, but was replaced by another from the list.

\section{Blood Sampling}

Personnel from the local livestock organization, trained in blood sampling of cattle, visited the participating herds on 4 occasions at approximately 2 -wk intervals. The start of blood sampling in each herd was when the greatest number of eligible primiparous cows was available for sampling. At the first visit, the personnel were instructed to sample all primiparous cows that were within approximately 2 wk before expected calving to $2 \mathrm{wk}$ after actual calving. At the second visit they resampled the cows sampled at the first visit, and sampled all new primiparous cows that were within approximately 2 wk before expected calving to 2 wk after actual calving. At the third and fourth visit they only sampled animals already sampled at previous occasions. During the study period a total of 298 primiparous cows ( 7 to 22 primiparous cows/herd, median 16 primiparous cows/herd) were blood sampled. Of these cows $6(2 \%), 9(3 \%), 87(29 \%)$, and $196(66 \%)$ were sampled 1, 2, 3, and 4 times, respectively.

At each sampling two 5-mL vacutainer tubes without additives (Becton Dickinson Vacutainer Systems, Cow- ley, UK) were taken from the coccygeal vein of each animal. The blood samples were transported chilled to the laboratory (National Veterinary Institute, Uppsala, Sweden) within $24 \mathrm{~h}$ after sampling. At arrival, the samples were centrifuged at $1,000 \times g$ for $30 \mathrm{~min}$ at room temperature. Sera were harvested and stored at $-20^{\circ} \mathrm{C}$ for later analysis. All samples were analyzed for NEFA, BHBA, glucose, insulin, urea nitrogen, and haptoglobin. For financial reasons only the first 2 samples after calving were analyzed for conglutinin and CL-43, and $\alpha$-tocopherol and selenium were only analyzed in one sample per animal taken -5 to $+5 \mathrm{~d}$ relative to calving.

\section{Serum Analyses}

Serum concentrations of BHBA, cholesterol, glucose, haptoglobin, insulin, NEFA, and urea nitrogen were analyzed in 976 samples taken from the 291 primiparous cows that were sampled in the period from -14 to $60 \mathrm{~d}$ after calving. The CL-43 and conglutinin were analyzed in 541 samples taken from 283 primiparous cows in the period 0 to $32 \mathrm{~d}$ after calving. Selenium and $\alpha$-tocopherol were analyzed in one sample per cow taken from those primiparous cows (172) that had been sampled in the period -5 to +5 d relative to calving at one of the visits.

The NEFA, BHBA, glucose, and urea nitrogen were analyzed using methods described previously (Mashek et al., 2001) using the auto analyzer, ADVIA 1650 (Bayer Corporation, Tarrytown, NY). Total cholesterol was determined by enzymatic hydrolysis of cholesterol esters and concomitant enzymatic liberation of hydrogen peroxide (Trinder process) using a standard diagnostic kit (Kolesterol REF: 01482198; Siemens Medical Solutions Diagnostics, Ballerup, Denmark). The intraassay coefficients of variation $(\mathrm{CV} \%)$ of this analysis were $<2 \%$, in general, and always $<5 \%$. The interassay CV\% was $<3 \%$, in general, and always $<5 \%$. The inaccuracy (relative bias) was $<5.5 \%$. Insulin was measured using an insulin noncompetitive time-resolved immunofluorometric assay as described previously by Løvendahl and Purup (2002). The intraassay CV\% was 15, 5.4 , and 4.9 , and the interassay CV\% was $0,8.0$, and 4.7, for the low (18.8 $\mathrm{p} M)$, intermediate $(78 \mathrm{p} M)$, and high $(363 \mathrm{pM})$ control sample, respectively.

Haptoglobin was determined by its ability to bind to hemoglobin (Phase RANGE, Tridelta Developments, Wicklow, Ireland) using the auto analyzer, ADVIA 1650 (Bayer Corporation). The intraassay CV\% was 1.5 and 0.6 , and the interassay CV\% was 0.9 and 2.2 , for the low and high control sample, respectively. The inaccuracy was $-8.5 \%$ and $+1.0 \%$, for low and high controls, respectively. 
Conglutinin and CL-43 were analyzed as described by Krogh-Meibom et al. (2004a,b). For conglutinin the intraassay CV\% was 13.9 and 9.2, and the interassay CV\% was 0 and 3.1 , for the low $(299 \mathrm{ng} / \mathrm{mL})$ and high $(12,300 \mathrm{ng} / \mathrm{mL})$ control sample, respectively. For CL-43 the intraassay CV\% was $10.5,10.6$, and 9.8 , and the interassay CV\% was $10.3,6.6$, and 6.2 , for the low $(24.8$ $\mathrm{ng} / \mathrm{mL})$, intermediate $(45.8 \mathrm{ng} / \mathrm{mL})$, and high $(75.9 \mathrm{ng} /$ $\mathrm{mL}$ ) control sample, respectively.

Concentrations of $\alpha$-tocopherol were measured as described by Meglia et al. (2006), whereas selenium was determined using hydrid generation inductively coupled serum atomic emission spectrometry (ICP-AES, Jobin Yvon 238 emission-spectrometer, Jobin Yvon S.A.S., Longjuemeau, Cedex, France) with set-up and conditions according to methods accredited by SWEDAC (Swedish Board for Accreditation and Conformity assessment, Borås, Sweden).

All metabolic and immunological variables except selenium were analyzed at the Department of Animal Health, Welfare and Nutrition, Faculty of Agricultural Sciences, Tjele, Denmark. Analyses of selenium were performed at the Department of Chemistry, National Veterinary Institute, Uppsala, Sweden.

\section{Collection of Animal Data}

Information on age at calving, breed, and cow composite SCC at first test-milking for primiparous cows included in the blood sampling was collected from the SOMRS and SADRS throughout the study period. Somatic cell count was measured using Fossomatic cell counter (Fossomatic 5000, Foss, Hillerød, Denmark).

\section{Statistics}

Ordinary linear regression models, but with robust $\mathrm{SE}$ and adjusting for clustering within herds using the robust and cluster options in Stata Software (Stata Statistical Software: Release 9.2, StataCorp LP, College Station, TX), were used to investigate associations between the blood variables and SCC at first test-milking. The robust and cluster options substitute a robust variance matrix calculation for the conventional calculation and allows relaxing the assumption of independence within groups (adjusts the SE for intragroup correlation; Froot, 1989).

Only the samples taken closest before (median $7 \mathrm{~d}$ before, range 14 to $1 \mathrm{~d}$ before) or after (median $8 \mathrm{~d}$ after, range 1 to $21 \mathrm{~d}$ after) calving were used in the statistical analysis of associations between metabolites and SCC at first test-milking because the main interest of the study was effects of the status around calving, provided they were taken before first test-milking. A total of 152 animals had both a before-calving and an after-calving value. Delta values for BHBA, cholesterol, glucose, insulin, NEFA, and urea nitrogen were calculated as the value after calving minus the value before calving divided by number of days between the before and after value. For the statistical analysis of associations among $\alpha$-tocopherol and selenium, or immunological variables, and SCC at first test-milking, all blood samples analyzed were used.

The SCC at first test-milking was the dependent variable, transformed using Box-Cox transformation (bcSCC; [(SCC/1,000)-0.288] - 1\}/-0.288) to obtain normally distributed residuals using the bcskew0 statement in Stata that creates a new variable that is BoxCox power transformed $\left.\left[\left(\exp ^{\mathrm{L}}\right)-1\right) / \mathrm{L}\right]$, choosing $\mathrm{L}$ so that the skewness of the new variable is zero. The primiparous cows in this study had very low SCC and just a few individuals with greater SCC, creating a skewed variable that became more normally distributed using bcSCC than, for example, lnSCC. The concentrations of the blood variables and their change (delta values) from before to after calving were explanatory variables.

Associations between the dependent variable (bcSCC) and each of the explanatory variables were first screened in univariable regression analysis. Variables with a $P$-value $\leq 0.20$, provided there was no collinearity $(\mathrm{r}<0.70)$ between variables, were then considered for multivariable analysis. The before calving, after calving, and delta values could not be included simultaneously because of their interdependence. Significant delta values were combined with the before- or aftercalving values depending on which was more significantly associated with the outcome. The model was then reduced using a manual stepwise backward variable selection procedure, and variables with a $P$-value of $\leq 0.05$ were retained in the model. If neither the before nor the after value, included in combination with the delta value, was significant, the before or the after value that had not been included when the combination was tested was then tested in the model without the delta value. The quadratic term (centered using the median values) of all variables was tested, provided that the collinearity between the linear and quadratic term was $<0.70$. Three separate multivariable models were constructed: one including blood variables related to metabolism (BHBA, cholesterol, glucose, insulin, NEFA, and urea nitrogen), one including $\alpha$-tocopherol and selenium (not included in the metabolism model because of different recording schemes and limited number of samples), and one including blood variables related to immunology (CL-43, conglutinin, and haptoglobin). To adjust for differences in SCC due to the effect of calving and onset of lactation, the linear term of DIM (centered using the median DIM) was used as adjusting factor in 
the models. To adjust for differences in the explanatory variables due to the effect of calving and onset of lactation, the linear term of days from sampling to calving (DFC; centered using the median DFC) was used as adjusting factor in the metabolism and immunology models. For all 3 models, interactions between all variables included were tested and retained if the $P$-value was $\leq 0.05$.

Model validation was performed according to Dohoo et al. (2003). The normality of residuals was assessed by looking at normal probability plots of the residuals and standardized residuals ( $\mathrm{Q}-\mathrm{Q}$ plot) as well as by looking at the plot of standardized residuals against the fitted values. Influential points and outliers were identified by looking at Cook's distance values, leverage and difference in fit (DFITS) values.

Hierarchical linear regression models, with herd as random factor and repeated measures of the dependent variable, were used to investigate the effect of period (days from calving), breed (SR and SH breed), and age at calving on all blood variables, except $\alpha$-tocopherol and selenium where only one record per animal was available. Due to the low number of crossbred animals $(\mathrm{n}=13)$ these were not included in the hierarchical linear regression models. Days from calving was divided into 13 periods; -14 to $-8,-7$ to $-3,-2$ to 2,3 to 7,8 to 12,13 to 17,18 to 22,23 to 27,28 to 32,33 to 37,38 to 42,43 to 52 , and 53 to $60 \mathrm{~d}$ after calving. The length of the periods was chosen so that number of observation was large enough to compare cows of different breed and age at calving in each period. Age at calving was divided to obtain 3 equally large categories; $<25 \mathrm{mo}, 25$ to $27 \mathrm{mo}$, and $>27 \mathrm{mo}$. All blood variables studied, except urea nitrogen, were transformed to obtain normally distributed residuals. The optimal transformation was determined with the aid of the guided data analysis applied in the SAS/LAB software, based on a simplified main-effects model, but the normality of the residuals was retested after the complete analysis to confirm the correctness of the transformations. Thus, BHBA, conglutinin and CL-43 were transformed to a logarithmic scale with base 10, NEFA was transformed to $\mathrm{NEFA}^{-0.3}$, insulin to insulin ${ }^{0.2}$, glucose to glucose ${ }^{2}$, cholesterol to the $\sqrt{ }$ cholesterol, haptoglobin to haptoglo$\mathrm{bin}^{-0.7}$. The hierarchical linear regression analyses were performed using the MIXED procedure (Littell et al., 1996) of SAS (Release 9.1, SAS Institute Inc., Cary, NC), with the REPEATED and RANDOM statements, and the compound symmetry covariance structure. A manual backward variable selection procedure was used including all main effects and all 2-way interactions. To illustrate differences between breeds over time, least squares means were calculated for the inter- action between period and breed and back-transformed to the observed scale, when necessary.

Intraclass correlations (ICC; $\rho$ ) were calculated from the variance components obtained from the hierarchical linear regression models. The ICC between samples from different cows in the same herd was calculated as $\rho=\frac{\sigma_{h}^{2}}{\sigma_{h}^{2}+\sigma_{c}^{2}+\sigma^{2}}$, and the ICC between samples of the same cow was calculated as $\rho=\frac{\sigma_{h}^{2}+\sigma_{c}^{2}}{\sigma_{h}^{2}+\sigma_{c}^{2}+\sigma^{2}}$, where $\sigma_{h}^{2}$ is the variance between herds, $\sigma_{c}^{2}$ the variance within herd (between cows in the same herd), and $\sigma^{2}$ the variation within cow (between samples).

\section{RESULTS}

\section{Descriptive Data}

The arithmetic mean annual herd size and milk production for the 20 herds were 205 cows [50\% central range (CR; excluding $25 \%$ of the values at each end of the distribution]: 135 to 234 cows) and $10,290 \mathrm{~kg}$ of milk/cow-year (50\% CR: 9,430 to $11,100 \mathrm{~kg}$ of milk/cowyear), respectively. The geometric mean BMSCC was 204,000 cells/mL (50\% CR: 170,000 to 242,000 cells/ $\mathrm{mL}$ ). The geometric mean SCC at first test-milking (occurring on average $21 \mathrm{~d}$ after calving) for primiparous cows included in the statistical analysis of associations between blood variables and SCC was 62,700 cells $/ \mathrm{mL}$ (50\% CR: 31,000 - 105,000 cells $/ \mathrm{mL}$ ) corresponding to a bcSCC of 2.42. The arithmetic mean age at calving for the 298 sampled primiparous cows was $25.6 \mathrm{mo}$ (50\% CR: 24.4 to $27.1 \mathrm{mo}$ ), and the number of cows in the groups $<25$ mo of age, 25 to 27 mo of age, and $>27$ mo of age at calving, was 110,112 , and 76 , respectively. The majority of the cows were of the SH-breed (65\%), whereas $31 \%$ were of the SR-breed and $4 \%$ were crossbred (SH/SR). Crossbred cows was excluded from the statistical analyzes due to the low number $(n=13)$ of crossbred cows.

Median values for the before calving concentrations, the after calving concentrations and the calculated delta values for BHBA, cholesterol, glucose, insulin, NEFA, and urea nitrogen are presented in Table 1.

Arithmetic mean serum concentrations at various time periods (if $>5$ samples/period) for all blood variables, except for $\alpha$-tocopherol and selenium, are shown in Figure 1. The arithmetic mean serum concentrations of $\alpha$-tocopherol and selenium were $2.13 \mathrm{mg} / \mathrm{L}$ (50\% CR: 1.56 to $2.55 \mathrm{mg} / \mathrm{L}$ ) and $0.06 \mu \mathrm{g} / \mathrm{g}$ (50\% CR: 0.04 to 0.07 $\mu \mathrm{g} / \mathrm{g})$, respectively. 
Table 1. Median (1st quartile; 3rd quartile) concentrations before and after calving, and delta values [the difference between the after and before calving concentrations divided with number of days between the samplings (11-16 d)] of blood metabolites measured in the period -14 to $+14 \mathrm{~d}$ relative to calving in blood samples from 152 first-parity cows in 20 Swedish dairy herds

\begin{tabular}{lccc}
\hline Blood variable & Before calving $^{1}$ & After calving & Delta value \\
\hline BHBA, mmol/L & $0.59(0.47 ; 0.71)$ & $0.64(0.54 ; 0.78)$ & $0.002(-0.006 ; 0.01)$ \\
Cholesterol, mmol/L & $2.62(2.22 ; 2.99)$ & $2.88(2.38 ; 3.23)$ & $0.02(-0.02 ; 0.05)$ \\
Glucose, $\mathrm{mmol} / \mathrm{L}$ & $3.24(2.78 ; 3.66)$ & $3.10(2.72 ; 3.48)$ & $-0.007(-0.04 ; 0.03)$ \\
Insulin, $\mathrm{pmol} / \mathrm{L}$ & $60.9(40.6 ; 98.1)$ & $35.3(23.2 ; 56.8)$ & $-1.79(-3.82 ; 0.30)$ \\
NEFA, $\mu \mathrm{Eq} / \mathrm{L}$ & $143.5(108.6 ; 228.9)$ & $292.9(194.8 ; 449.8)$ & $8.37(1.11 ; 19.4)$ \\
Urea nitrogen, $\mathrm{mmol} / \mathrm{L}$ & $4.39(3.66 ; 5.36)$ & $4.05(3.25 ; 4.91)$ & $-0.03(-0.09 ; 0.02)$ \\
\hline
\end{tabular}

${ }^{1} 14$ to $1 \mathrm{~d}$ before calving.

${ }^{2} 1$ to $14 \mathrm{~d}$ after calving.

\section{Associations Between Blood Variables and SCC at First Test-Milking}

The results of the analysis of metabolites associated with bcSCC (Table 2) showed that greater concentrations of BHBA and glucose before calving were associated with lesser bcSCC, while greater concentrations of NEFA before calving, as well as greater delta NEFA values, were associated with greater bcSCC. Calculated SCC changes for a decrease/increase from the median to the first/third quartile for respective variable in the model are included in Table 2.

In the analysis of associations among serum $\alpha$-tocopherol and serum selenium, and bcSCC, only $\alpha$-tocopherol remained significant (Table 3). A greater $\alpha$-tocopherol concentration in the period -5 to $+5 \mathrm{~d}$ relative to calving was associated with a lesser bcSCC. Calculated SCC changes for a decrease/increase from the median to the first/third quartile in $\alpha$-tocopherol are included in Table 3.

The results of the analysis of immune variables associated with bcSCC (Table 4) showed that greater concentrations of serum CL-43 postpartum ( 1 to $21 \mathrm{~d}$ after calving) were associated with greater bcSCC. Moreover, the interaction term between conglutinin and haptoglobin was associated with bcSCC. Calculated SCC changes for a decrease/increase from the median to the first/third quartile for respective variable in the model are included in Table 4.

All models showed a reasonably good fit, with only a few outliers with influential values. The models fit improved somewhat if the outliers were removed, but because there was no reason to disbelieve the blood values from these animals they were retained in the final models.

\section{Associations Among Blood Variables and Period, Breed, and Age at Calving}

Period was significantly associated with all variables (Table 5), but only as an interaction term with breed for cholesterol, NEFA, and CL-43. Breed as main effect was significantly associated with insulin, urea nitrogen, and conglutinin. The LSM for the interaction between period and breed for all variables, adjusted by significant main effects, are presented in Figures 2 and 3. Age at calving as main effect was significantly associated with BHBA, glucose, insulin, NEFA, urea nitrogen, and conglutinin. Heifers calving at an older age (>27 mo) had greater BHBA and NEFA, and lesser glucose, insulin and urea nitrogen values compared with heifers calving at a younger age $(<27 \mathrm{mo})$. Heifers calving at an even younger age $(<25 \mathrm{mo})$ had greater conglutinin and urea nitrogen, and lesser NEFA values compared with heifers calving at an older age $(>25 \mathrm{mo})$. Heifers aged $<25$, and 25 to $27 \mathrm{mo}$ at calving had similar BHBA, glucose, and insulin values, whereas heifers aged 25 to 27 , and $>27$ mo at calving had similar conglutinin values.

The results of the calculations of ICC (Table 5) showed that the distributions of the fractions of variance for the different blood variables at herd and cow level differed. The CL-43, conglutinin, and cholesterol had very little variation between samples within cow, and a very large variation between samples within herd. Haptoglobin had a large variation both in samples within cow and in samples within herd. The variations for glucose and urea nitrogen were similar between samples within cow and samples within herd. BHBA, insulin, and NEFA varied relatively much between samples both within cow and within herd, but most within herd.

\section{DISCUSSION}

The findings in the present study support the idea that metabolism can influence udder health, as greater concentrations of BHBA and glucose before calving, and of $\alpha$-tocopherol at calving, were associated with lesser bcSCC at first test-milking. Additionally, greater concentrations of NEFA before calving, and greater delta 


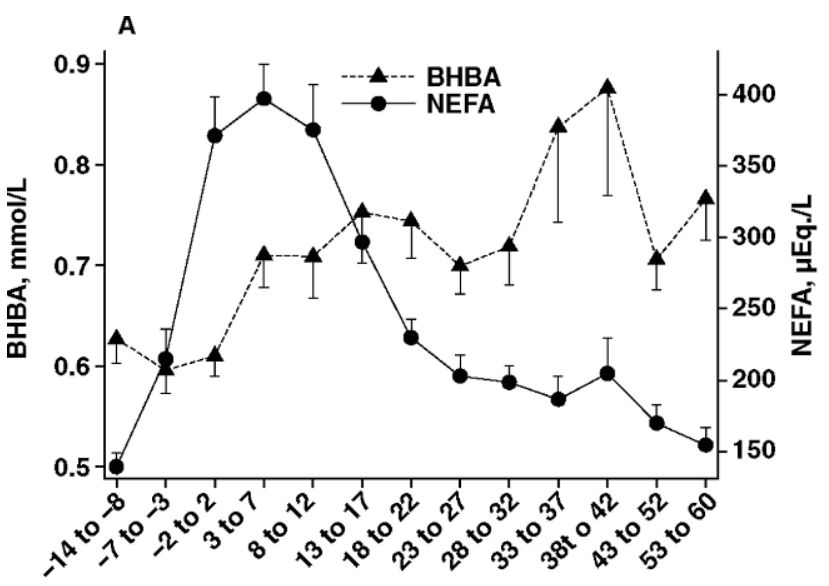

Days from calving
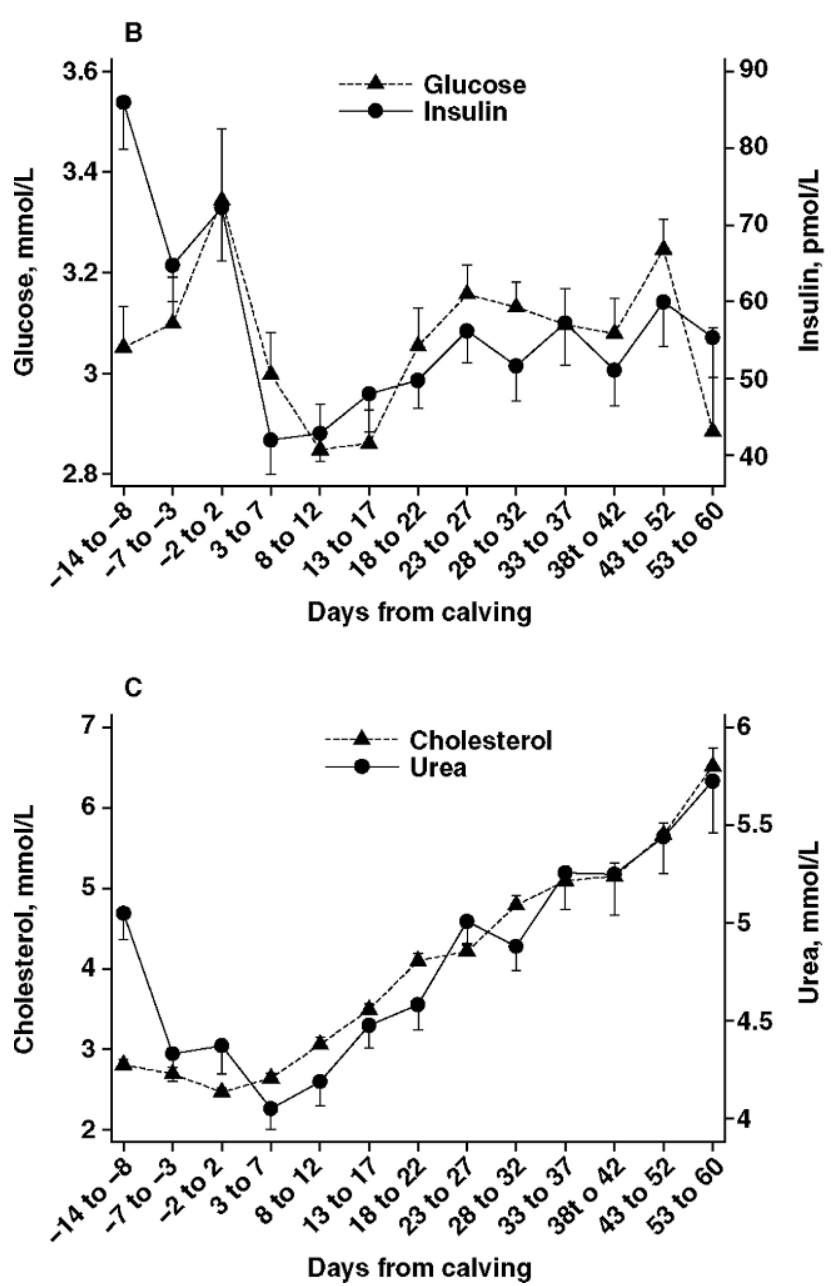

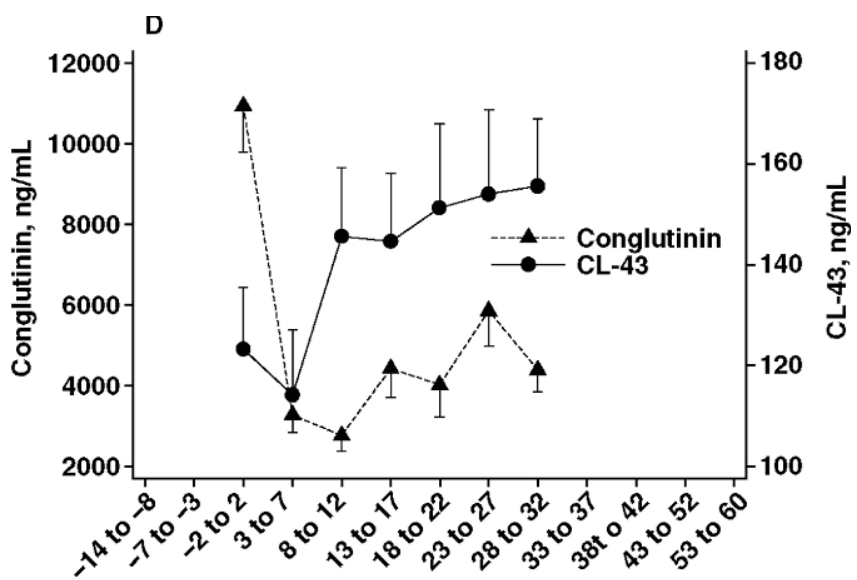

Days from calving

$\mathrm{E}$

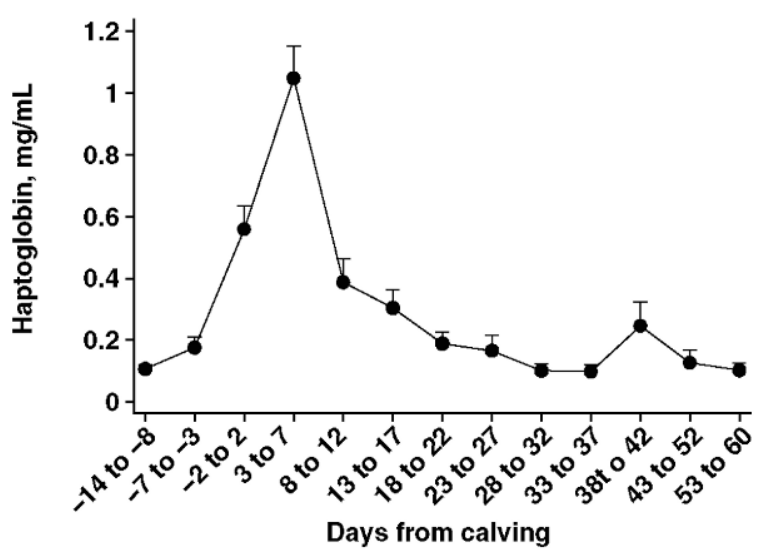

Figure 1. Serum concentrations (arithmetic means \pm SEM) of BHBA and NEFA (A), glucose and insulin (B), cholesterol and urea nitrogen (C), conglutinin and CL-43 (D), and haptoglobin (E) in primiparous cows ( $\mathrm{n}=283$ to 291) from 20 Swedish dairy herds.

NEFA were associated with a greater bcSCC at firsttest milking.

The negative relationship between plasma concentration of BHBA before calving and bcSCC may seem intri- guing because it is generally assumed that greater concentrations of BHBA are associated with impaired immune functions (Suriyasathaporn et al., 2000; Burvenich et al., 2007). However, the BHBA concentra- 
Table 2. Final linear regression model of associations between metabolic variables around parturition and Box-Cox transformed ${ }^{1}$ SCC at first test-milking in 152 primiparous cows in 20 Swedish dairy herds $\left(\mathrm{R}^{2}=0.25\right)$

\begin{tabular}{|c|c|c|c|c|c|c|c|c|}
\hline Variable & $\beta$ & $\mathrm{SE}(\beta)$ & $P$ & $\begin{array}{c}\text { 1st } \\
\text { quartile }\end{array}$ & Median & $\begin{array}{c}\text { 3rd } \\
\text { quartile }\end{array}$ & $\begin{array}{l}\text { Calculated SCC } \\
\text { change for a } \\
\text { decrease from } \\
\text { the median to } \\
1 \text { st quartile } \\
\text { in respective } \\
\text { variable }\end{array}$ & $\begin{array}{l}\text { Calculated SCC } \\
\text { change for an } \\
\text { increase from } \\
\text { the median to } \\
\text { 3rd quartile } \\
\text { in respective } \\
\text { variable }\end{array}$ \\
\hline Intercept & 2.55 & 0.10 & - & - & - & - & $47,300^{2}$ & $47,300^{2}$ \\
\hline Glucose (before calving), ${ }^{4} \mathrm{mmol} / \mathrm{L}$ & -0.06 & 0.02 & 0.01 & 2.83 & 3.26 & 3.68 & $+3,900$ & $-3,500$ \\
\hline NEFA (before calving), ${ }^{4} \mu \mathrm{Eq} / \mathrm{L}$ & 0.0006 & 0.0001 & $<0.0001$ & 102.29 & 136.13 & 227.38 & $-2,700$ & $+8,500$ \\
\hline Delta NEFA, ${ }^{5} \mu \mathrm{Eq} / \mathrm{L}$ & 0.003 & 0.0008 & 0.001 & 1.11 & 8.37 & 19.41 & $-3,100$ & $+5,300$ \\
\hline
\end{tabular}

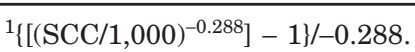

${ }^{2}$ Box-Cox transformed SCC back transformed to SCC (cells/mL), using the median values of the variables.

${ }^{3} \mathrm{DFC}=$ days from sampling to calving.

${ }^{4}$ Samples taken 14 to $1 \mathrm{~d}$ before calving.

${ }^{5}$ Delta NEFA = [NEFA value after calving (taken 1 to $21 \mathrm{~d}$ after calving) - NEFA value before calving (taken 14 to $1 \mathrm{~d}$ before calving)]/ days between samples.

tion during the period before calving, when the ketogenesis activity is small, is markedly lesser, in general, than in early lactation and does probably not reach a concentration affecting immune functions. During the microbial digestion of carbohydrates in the rumen large amounts of butyrate are produced, which are largely metabolized to BHBA in the rumen epithelium. The BHBA emanating from butyrate may have a significant influence on the BHBA concentration in plasma (Kristensen et al., 2000). In late lactation and during the dry period BHBA has been show to be positively related to energy balance (Chilliard et al., 1995; Odensten et al., 2005). Thus, the BHBA concentration in plasma before calving may mainly reflect dietary intake of rumen digestible carbohydrates and not NEB. It is interesting that greater NEFA concentration in serum before calving was associated with greater bcSCC. Elevated concentrations of NEFA prepartum have been reported to be associated with an increased risk of displaced abomasum after parturition (Cameron et al., 1998), and it has recently been suggested that NEFA sampled 1 or 2 wk before calving could be used to identify cows that will suffer from retained placenta, metritis, hepatic lipidosis, and ketosis postpartum (Bouda et al., 2007). However, we are not aware of any previous studies showing an association between NEFA before calving and SCC. The positive association between delta NEFA and bcSCC indicated that animals with large increases in NEFA (i.e., a large mobilization of fat from the adipose tissue at calving) may have impaired udder health, which is consistent with results reviewed by Burvenich et al. (2007). There was no interaction between the delta NEFA value and the before-calving NEFA value (i.e., the effect of an increased NEFA on bcSCC was the same for animals with smaller or greater NEFA before calving), indicating that the process lead-

Table 3. Final linear regression model of the association between the serum $\alpha$-tocopherol concentration close to parturition ( -5 to +5 d relative to calving) and Box-Cox transformed ${ }^{1}$ SCC at first test-milking in 172 primiparous cows in 20 Swedish dairy herds $\left(R^{2}=0.14\right)$

\begin{tabular}{|c|c|c|c|c|c|c|c|c|}
\hline Variable & $\beta$ & $\mathrm{SE}(\beta)$ & $P$ & $\begin{array}{c}1 \text { st } \\
\text { quartile }\end{array}$ & Median & $\begin{array}{c}\text { 3rd } \\
\text { quartile }\end{array}$ & $\begin{array}{l}\text { Calculated SCC } \\
\text { change for a } \\
\text { decrease from } \\
\text { the median to } \\
\text { 1st quartile } \\
\text { in respective } \\
\text { variable }\end{array}$ & $\begin{array}{l}\text { Calculated SCC } \\
\text { change for an } \\
\text { increase from } \\
\text { the median to } \\
\text { 3rd quartile } \\
\text { in respective } \\
\text { variable }\end{array}$ \\
\hline Intercept & 2.49 & 0.05 & - & - & - & - & $57,400^{2}$ & $57,400^{2}$ \\
\hline DIM (centered) & -0.01 & 0.003 & 0.002 & - & - & - & - & - \\
\hline$\alpha$-Tocopherol, mg/L & -0.05 & 0.02 & 0.03 & 1.56 & 2.01 & 2.54 & $+4,500$ & $-4,800$ \\
\hline
\end{tabular}

${ }_{1}\left\{\left[(\mathrm{SCC} / 1,000)^{-0.288}\right]-1\right\} /-0.288$.

${ }^{2}$ Box-Cox transformed SCC back transformed to SCC (cells $/ \mathrm{mL}$ ), using the median values of the variables. 
Table 4. Final linear regression model of associations between immunological variables in blood after parturition ( 1 to $21 \mathrm{~d}$ after calving) and Box-Cox transformed ${ }^{1}$ SCC at first test-milking in 243 primiparous cows in 20 Swedish dairy herds $\left(R^{2}=0.13\right)$

\begin{tabular}{|c|c|c|c|c|c|c|c|c|}
\hline Variable & $\beta$ & $\operatorname{SE}(\beta)$ & $P$ & $\begin{array}{c}\text { 1st } \\
\text { quartile }\end{array}$ & Median & $\begin{array}{c}\text { 3rd } \\
\text { quartile }\end{array}$ & $\begin{array}{l}\text { Calculated SCC } \\
\text { change for a } \\
\text { decrease from } \\
\text { the median to } \\
\text { 1st quartile } \\
\text { in respective } \\
\text { variable }\end{array}$ & $\begin{array}{l}\text { Calculated SCC } \\
\text { change for an } \\
\text { increase from } \\
\text { the median to } \\
\text { 3rd quartile } \\
\text { in respective } \\
\text { variable }\end{array}$ \\
\hline Intercept & 2.32 & 0.04 & - & & & & $50,900^{2}$ & $50,900^{2}$ \\
\hline Conglutinin, $\mathrm{ng} / \mathrm{mL}$ & -0.0000003 & 0.000005 & $\mathrm{NA}^{4}$ & 430.50 & $1,647.00$ & $5,305.20$ & NA & NA \\
\hline Haptoglobin, mg/mL & 0.03 & 0.02 & NA & 0.06 & 0.23 & 0.95 & NA & NA \\
\hline \multirow[t]{4}{*}{ Conglutinin $\times$ haptoglobin } & -0.00001 & 0.000006 & 0.04 & & -5 & & $-100(\mathrm{n}=6)$ & $-900(\mathrm{n}=22)$ \\
\hline & & & & & $-^{6}$ & & $+600(\mathrm{n}=19)$ & $-1,900(\mathrm{n}=33)$ \\
\hline & & & & & -7 & & $+4,000 \quad(\mathrm{n}=39)$ & $-5,600(\mathrm{n}=3)$ \\
\hline & & & & & -8 & & $-100(\mathrm{n}=6)$ & $+4,000 \quad(\mathrm{n}=39)$ \\
\hline
\end{tabular}

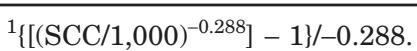

${ }^{2}$ Box-Cox transformed SCC back transformed to SCC (cells/mL), using the median values of the variables.

${ }^{3} \mathrm{DFC}=$ days from calving to sampling.

${ }^{4} \mathrm{NA}=$ not applicable.

${ }^{5}$ Evaluated for a change in conglutinin at 1st quartile of haptoglobin.

${ }^{6}$ Evaluated for a change in conglutinin at median haptoglobin.

${ }^{7}$ Evaluated for a change in conglutinin at at 3rd quartile of haptoglobin.

${ }^{8}$ Evaluated for a change in haptoglobin at 1st quartile of conglutinin.

${ }^{9}$ Evaluated for a change in haptoglobin at median conglutinin.

${ }^{10}$ Evaluated for a change in haptoglobin at 3rd quartile of conglutinin.

ing to an increase is more important for udder health than the actual postcalving concentration. The serum glucose concentration before calving was negatively associated with bcSCC. Glucose is an important energy source for immune cells (Calder, 1995), and it is thus possible that the greater glucose concentration aided the function of the immune cells, which in turn reduced the bcSCC. Taken together these results indicate that the metabolism before calving may influence the SCC at the first test milking in primiparous cows.

The lack of association between serum urea nitrogen and SCC found in this study could partly be due to the sampling time. In the present study, only a few blood samples were taken at the day of first test-milking, and

Table 5. Results from the hierarchical linear regression analysis of associations between serum concentrations of different blood variables of Swedish primiparous dairy cows during -14 to $60 \mathrm{~d}$ after calving, and period (P; days from calving), breed (B), age at calving (A), and their interaction terms,${ }^{1}$ including herd as random factor and using repeated values by cow

\begin{tabular}{|c|c|c|c|c|c|c|}
\hline \multirow[b]{3}{*}{ Dependent variable } & \multirow{2}{*}{\multicolumn{4}{|c|}{$P$-value }} & \multicolumn{2}{|c|}{ ICC } \\
\hline & & & & & \multirow{2}{*}{$\begin{array}{l}\text { Between samples } \\
\text { within herd }\end{array}$} & \multirow{2}{*}{$\begin{array}{l}\text { Between samples } \\
\text { within cow }\end{array}$} \\
\hline & $\mathrm{P}$ & B & A & $\mathrm{P} \times \mathrm{B}$ & & \\
\hline Cholesterol, $\mathrm{mmol} / \mathrm{L}$ & $\mathrm{NA}^{3}$ & NA & NS & 0.007 & 0.06 & 0.55 \\
\hline Glucose, $\mathrm{mmol} / \mathrm{L}$ & $<0.0001$ & NS & 0.03 & NS & 0.16 & 0.19 \\
\hline Insulin, $\mathrm{pmol} / \mathrm{L}$ & $<0.0001$ & 0.02 & 0.02 & NS & 0.08 & 0.27 \\
\hline NEFA, $\mu \mathrm{Eq} / \mathrm{L}$ & NA & NA & $<0.0001$ & 0.009 & 0.13 & 0.34 \\
\hline Conglutinin, ng/mL & $<0.0001$ & 0.003 & 0.02 & NS & 0.05 & 0.51 \\
\hline Haptoglobin, mg/mL & $<0.0001$ & NS & NS & NS & 0.04 & 0.07 \\
\hline
\end{tabular}

\footnotetext{
${ }^{1}$ Interaction terms $\mathrm{P} \times \mathrm{A}$ and $\mathrm{B} \times \mathrm{A}$ were never significant, and therefore excluded from the table. Nonsignificant variables were not
} included in the final models. The calculated intraclass correlations (ICC) of the models are also presented.

${ }^{2} \mathrm{NS}=$ not significant.

${ }^{3} \mathrm{NA}=$ not applicable because the interaction term is significant. 

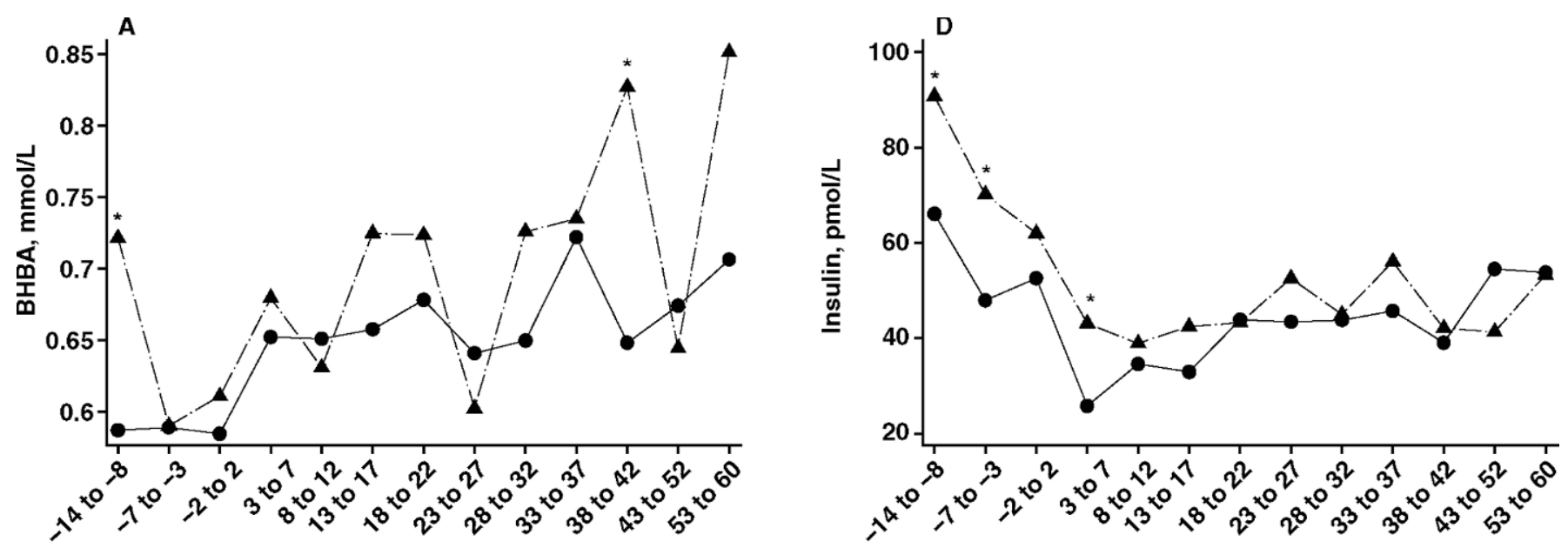

Days from calving
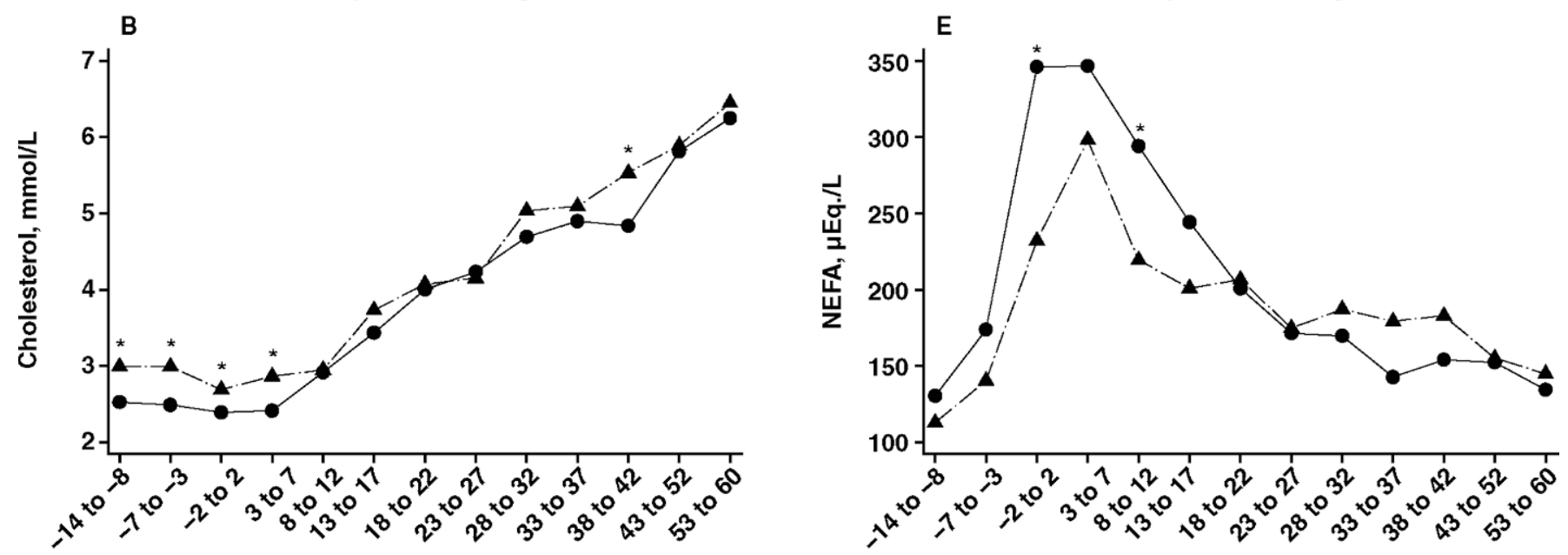

Days from calving
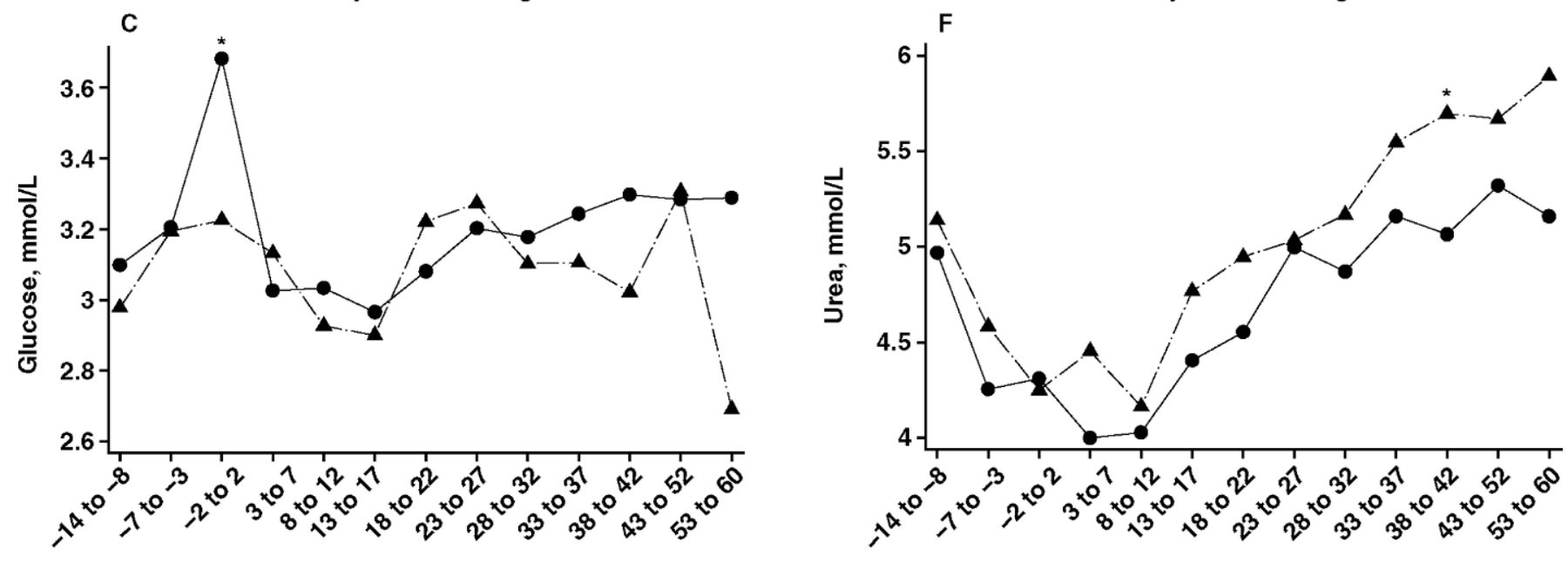

Days from calving

Days from calving

Figure 2. Serum concentrations [least squares means (LSM)] of BHBA (A), cholesterol (B), glucose (C), insulin (D), NEFA (E), and urea nitrogen $(\mathrm{F})$ by day relative to calving in primiparous cows $(\mathrm{n}=291)$ of the Swedish Holstein breed $(\mathbf{O})$ and Swedish Red breed $(-\mathbf{\Delta}-)$ from 20 Swedish dairy herds. All variables were adjusted for age at calving, except for cholesterol. *Significant $(P<0.05)$ differences between breeds in that period. 

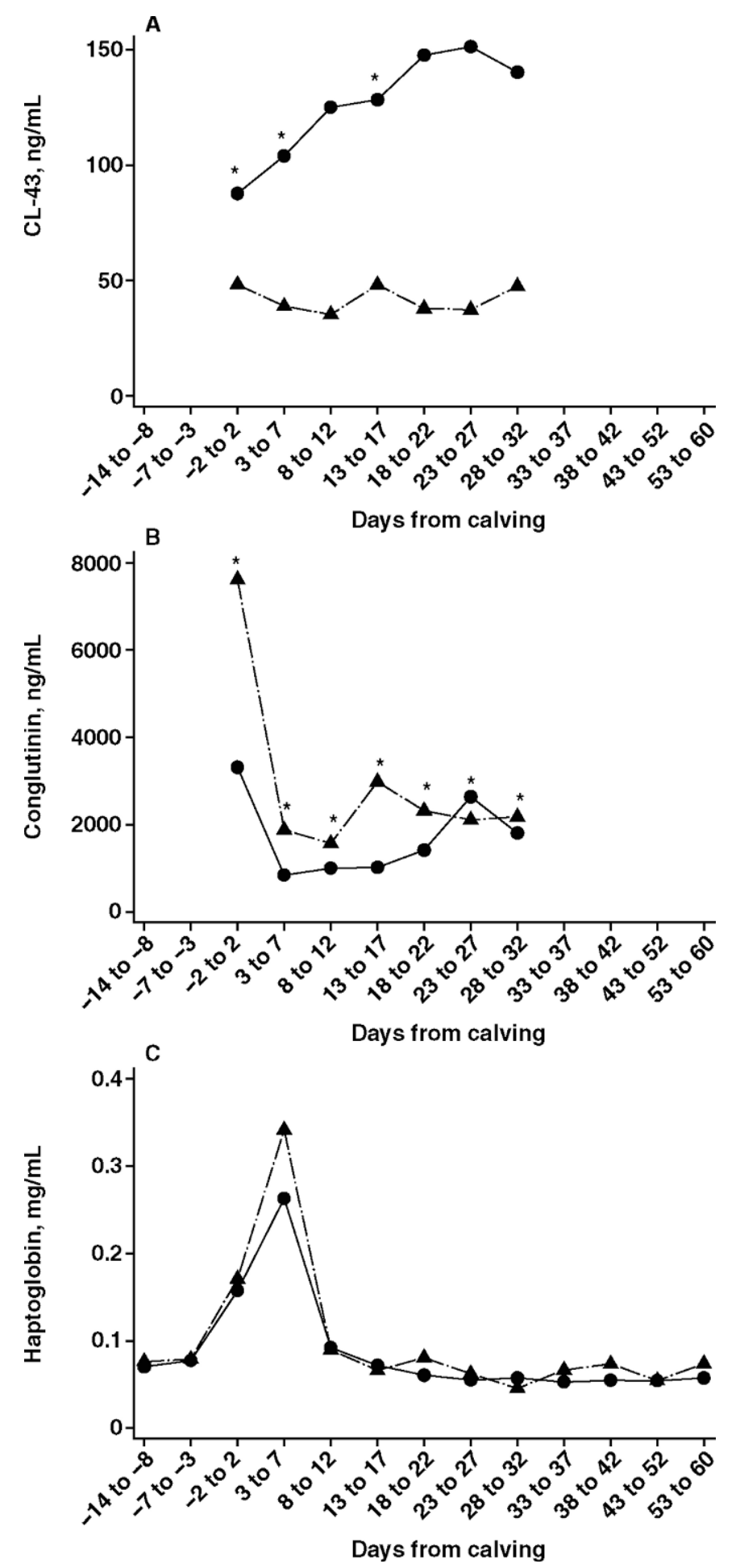

Figure 3. Serum concentrations [least squares means (LSM)] of CL-43 (A), conglutinin (B), and haptoglobin (C) by day relative to calving in primiparous cows $(n=283$ to 291$)$ of the Swedish Holstein breed (-) and Swedish Red breed ( $-\boldsymbol{\Delta}-$ ) from 20 Swedish dairy herds. The LSM for conglutinin was adjusted for age at calving. *Significant $(P<0.05)$ differences between breeds in that period. because the ICC results in the present study indicate that there is a large variation in urea nitrogen concentration within cow, difficulties in finding associations between blood samples and milk samples taken at different times could be expected. Studies using blood samples taken closer in time to milk sampling are needed to further investigate the association between blood urea nitrogen and SCC.

Of all the delta values entered in the metabolic model, only delta NEFA remained. That only one delta value remained was somewhat surprising because we expected that changes in metabolites occurring at and around calving would indicate more stress, possibly reflected on the udder health, than the actual concentrations before and after calving. The changes in metabolites are, however, very dynamic, and a simple delta value, as we choose to include, may not be sufficient in modeling the changes and their associations with udder health. Moreover, due to limitations in the number of blood samples per cow, we chose to construct the delta values from the samples taken closest before and after calving in each animal, which may not have been optimal. More elaborate ways to model the changes in metabolites around calving are therefore needed before we can reject our hypothesis.

In agreement with our findings of an association with greater $\alpha$-tocopherol at calving and low bcSCC at first test-milking, a favorable effect of periparturient supplementation of vitamin $\mathrm{E}$ on SCC has been reported previously (Smith et al., 1984; Baldi et al., 2000). Such an effect was not, however, found in a recent study in commercial herds (Persson Waller et al., 2007). We could not find any association between serum selenium concentrations at calving and bcSCC at first test-milking despite the relatively low selenium concentration found in serum with approximately $70 \%$ of the samples containing marginal $(0.03$ to $0.06 \mu \mathrm{g} / \mathrm{g})$ or deficient $(<0.025 \mu \mathrm{g} / \mathrm{g})$ concentrations according to Puls (1994). Previously, some studies have reported no association between selenium status and SCC, whereas other studies found lesser SCC with increasing concentration of selenium (Hemingway, 1999). On the other hand, an association between greater selenium concentration and greater SCC has also been found (Kommisrud et al., 2005). The variability in selenium concentration was low in the present study (data not shown), and low variability of an explanatory variable reduces the possibility to find significant association with the outcome measured.

The association between greater haptoglobin concentrations (in the interaction with low or mediate concentrations of conglutinin) after calving and greater bcSCC is in accordance with other studies where increased haptoglobin concentrations have been associated with 
infection and inflammation (Murata et al., 2004). Grönlund et al. (2003) did not, however, find elevated serum concentrations of haptoglobin during subclinical Staphylococcus aureus mastitis. In contrast to the association between haptoglobin and SCC mentioned above, the SCC has been reported to decrease with greater serum conglutinin activity concentrations (Kehrli et al., 1991). The results from the present study support that finding; greater conglutinin concentrations, especially at greater concentrations of haptoglobin, were associated with low bcSCC. The finding that a combination of greater haptoglobin and greater conglutinin concentrations was associated with the most marked decrease in SCC is intriguing. Greater concentrations of both proteins were mainly observed during the week around calving. Recently, Rezamand et al. (2007) found greater haptoglobin concentrations in plasma at $1 \mathrm{wk}$ after calving in cows without a new intramammary infection compared with in cows with a new intramammary infection. Thus, based on the results of present study as well as the results of Kehrli et al. (1991) and Rezamand et al. (2007) it may be hypothesized that greater concentrations of both haptoglobin and conglutinin at calving may be an indication of a well-functioning innate immune response. To our knowledge, the relationship between CL-43 and SCC has not been studied before. Thus, our finding that greater CL-43 concentrations were associated with greater bcSCC is interesting. However, the association between CL-43 and bcSCC, as well as the associations between conglutinin and haptoglobin, and bcSCC, disappeared when the data were corrected for breed (data not shown) because primiparous SH-cows had greater CL-43 and lesser conglutinin concentrations in early lactation and greater SCC at first test-milking compared with SR-cows.

The present study indicates that several blood variables of primiparous cows in the period around parturition and in early lactation differ between the 2 main Swedish dairy breeds, SR and SH. These findings may, at least partly, explain the observed difference in udder health, in favor of the SR, between these breeds (Swedish Dairy Association, 2006). The lesser concentrations of cholesterol and insulin, and greater concentrations of NEFA in primiparous SH-cows than in SR-cows imply that the SR-cows coped better with the transition from the nonlactating to the lactating stage. Cholesterol and insulin have previously been shown to be positively correlated, and NEFA negatively correlated with the energy balance of dairy cows (Reist et al., 2002). Other studies have found significant breed differences (Holstein vs. Jersey) in NEFA concentrations (Rastani et al., 2001; French, 2006). Moreover, French (2006) found a significant interaction between breed and time relative to calving for NEFA, which is in agreement with our results. Breed differences in blood concentrations of cholesterol and insulin have, to our knowledge, not been reported previously.

Breed differences were also observed in the concentrations of collectins with greater concentrations of conglutinin and lesser concentrations of CL-43 in SR-cows compared with SH-cows. An association between breed (Red Danes, Holsteins, Jerseys, and Red-Pieds) and conglutinin was also found in a Danish study by Holmskov et al. (1998), but in that study heifer calves of the Holstein breed had the greatest concentrations of conglutinin compared with the other breeds. Significant differences in conglutinin activity have also been found between sire progeny groups within the Holstein breed (Kehrli et al., 1991). An association between CL-43 concentrations and breed has, to our knowledge, not been described previously. The results of the present study suggest different roles of the 2 collectins in the period studied as their patterns differed markedly. Greater concentrations of conglutinin were found at calving than in early lactation, while the opposite was the case for CL-43. The increase in CL-43 after calving was, however, only observed in SH-cows. In contrast, the kinetics of the conglutinin values was similar in SRand SH-cows. The drop in conglutinin after calving is in line with findings by Ingram and Mitchell (1970). A marked drop in serum conglutinin has also been observed in connection with spontaneous abortion and acute systemic infections, but not in association with cases of clinical mastitis without systemic symptoms (reviewed by (Dec and Wernicki, 2006). Given the results on conglutinin and CL-43 found in the present study, and the superior udder health found in SR-cows compared with SH-cows (Swedish Dairy Association, 2006), further studies are needed on the roles of these collectins in the immune defense in early lactation, especially in association with udder infections.

In the present study, heifers calving at an older age had greater BHBA and NEFA concentrations, and lesser glucose, insulin, and urea nitrogen values compared with heifers calving at a younger age indicating that heifers calving at an older age were in more severe NEB in the period around parturition and in early lactation. One explanation for these associations is that the primiparous cows calving at an older age $(>27 \mathrm{mo})$ had a significantly greater milk production at first testmilking compared with primiparous cows calving at a younger age $(<27 \mathrm{mo}$; data not shown). A greater milk production in early lactation can negatively affect the energy balance if the cow is unable to increase her DMI. An association between metabolic disorders and age at calving, with a greater incidence of ketosis in heifers calving at an older age, has been reported previously (van Dam et al., 1988). In the present study, heifers 
calving at an older age also had lesser concentrations of conglutinin than younger heifers, which also may be due to the more severe metabolic condition of these animals; Ingram and Mitchell (1971) suggested that greater conglutinin concentrations are associated with good nutritional conditions.

Some practical implications for blood sampling, using a sampling strategy as in the present study, can be derived from the ICC results, although they need to be confirmed in other studies. For example, the small within-cow variation in CL-43 concentrations indicates that only a few samples are needed per cow for estimation of the CL-43 status. However, to get an estimate of the CL-43 status in the herd it is necessary to sample many cows. To estimate haptoglobin status each cow needs to be sampled several times and several cows must be sampled in a herd.

\section{CONCLUSIONS}

Blood concentrations of BHBA, glucose, and NEFA before calving, and of $\alpha$-tocopherol at calving, were associated with bcSCC at first test-milking of primiparous cows. The CL-43, conglutinin, and haptoglobin were also associated with bcSCC, but this association could not be separated from a direct breed effect. Breed and age at calving were significantly associated with several metabolites and immunological variables of primiparous cows in the period around parturition and in early lactation. The role of collectins in the defense against udder infections needs further investigations.

\section{ACKNOWLEDGMENTS}

The authors gratefully acknowledge the financial support from the Swedish Farmer's Foundation for Agricultural Research (Stockholm, Sweden) and the Swedish Dairy Association (Stockholm/Eskilstuna, Sweden). We would especially like to thank all participating farmers for their hospitality and cooperation, and the technicians for invaluable assistance. We would also like to express our gratitude to the technical staff at the laboratories at the Department of Pigs, Poultry and Ruminants at the National Veterinary Institute (Uppsala, Sweden) and at the Department of Animal Health, Welfare and Nutrition at the Faculty of Agricultural Sciences (Tjele, Denmark).

\section{REFERENCES}

Baldi, A., G. Savoini, L. Pinotti, E. Monfardini, F. Cheli, and V. Dell'Orto. 2000. Effects of vitamin E and different energy sources on vitamin $\mathrm{E}$ status, milk quality and reproduction in transition cows. J. Vet. Med. A Physiol. Pathol. Clin. Med. 47:599-608.

Bareille, N., H. Seegers, M. B. Kiebre-Toe, F. Beaudeau, and C. Fourichon. 2000. Risk factors for elevated milk somatic cell counts during early lactation in dairy heifers. Pages 509-514 in Proc. 10th Int. Congr. Anim. Hyg., Maastricht, the Netherlands. ADDIX, Wijk bij Duurstede, the Netherlands.

Barkema, H. W., Y. H. Schukken, T. J. Lam, M. L. Beiboer, H. Wilmink, G. Benedictus, and A. Brand. 1998. Incidence of clinical mastitis in dairy herds grouped in three categories by bulk milk somatic cell counts. J. Dairy Sci. 81:411-419.

Bouda, J., J. Ávila, K. Kawabata, G. Salgado, and J. Doubek. 2007. Prepartum serum concentration of free fatty acids and postpartum diseases in dairy cows. Page 388 in Production Diseases in Farm Animals. M. Fürll, ed. 13th Int. Conf. Prod. Dis. Farm Anim., Leipzig, Germany. Merkur Druck und Kupier, Zentrum, Germany.

Broderick, G. A., and M. K. Clayton. 1997. A statistical evaluation of animal and nutritional factors influencing concentrations of milk urea nitrogen. J. Dairy Sci. 80:2964-2971.

Burvenich, C., D. D. Bannerman, J. D. Lippolis, L. Peelman, B. J. Nonnecke, M. E. Kehrli, and M. J. Paape. 2007. Cumulative physiological events influence the inflammatory response of the bovine udder to Escherichia coli infections during the transition period. J. Dairy Sci. 90(E Suppl.):E39-E54.

Calder, P. C. 1995. Fuel utilization by cells of the immune system. Proc. Nutr. Soc. 54:65-82.

Cameron, R. E., P. B. Dyk, T. H. Herdt, J. B. Kaneene, R. Miller, H. F. Bucholtz, J. S. Liesman, M. J. Vandehaar, and R. S. Emery. 1998. Dry cow diet, management, and energy balance as risk factors for displaced abomasum in high producing dairy herds. J. Dairy Sci. 81:132-139.

Cavestany, D., J. E. Blanc, M. Kulcsar, G. Uriarte, P. Chilibroste, A. Meikle, H. Febel, A. Ferraris, and E. Krall. 2005. Studies of the transition cow under a pasture-based milk production system: Metabolic profiles. J. Vet. Med. A Physiol. Pathol. Clin. Med. $52: 1-7$.

Cebra, C. K., J. R. Heidel, R. O. Crisman, and B. V. Stang. 2003. The relationship between endogenous cortisol, blood micronutrients, and neutrophil function in postparturient Holstein cows. J. Vet. Intern. Med. 17:902-907.

Chilliard, Y., M. Doreau, F. Bocquier, and G. E. Lobley. 1995. Digestive and metabolic adaptations of ruminants to variations in food supply. Pages 329-360 in Recent Developments in the Nutrition of Herbivores. M. Journet, E. Grenet, M. H. Farce, M. Thériez, and C. Demarquilly, ed. INRA Publ., Paris, France.

Dec, M., and A. Wernicki. 2006. Conglutinin, CL-43 and CL-46-three bovine collectins. Pol. J. Vet. Sci. 9:265-275.

Dohoo, I. R., W. Martin, and H. Stryhn. 2003. Veterinary epidemiologic research. AVC Inc., Charlottetown, Prince Edward Island, Canada.

French, P. D. 2006. Dry matter intake and blood parameters of nonlactating Holstein and Jersey cows in late gestation. J. Dairy Sci. 89:1057-1061.

Froot, K. A. 1989. Consistent covariance matrix estimation with crosssectional dependence and heteroskedasticity in financial data. J. Financ. Quant. Anal. 24:333-355.

Grönlund, U., C. Hulten, P. D. Eckersall, C. Hogarth, and K. P. Waller. 2003. Haptoglobin and serum amyloid A in milk and serum during acute and chronic experimentally induced Staphylococcus aureus mastitis. J. Dairy Res. 70:379-386.

Hemingway, R. G. 1999. The influences of dietary selenium and vitamin $\mathrm{E}$ intakes on milk somatic cell counts and mastitis in cows. Vet. Res. Commun. 23:481-499.

Hogan, J. S., W. P. Weiss, D. A. Todhunter, K. L. Smith, and P. S. Schoenberger. 1992. Bovine neutrophil responses to parenteral vitamin E. J. Dairy Sci. 75:399-405.

Holmskov, U., J. C. Jensenius, I. Tornoe, and P. Lovendahl. 1998. The plasma levels of coglutinin are heritable in cattle and low levels predispose to infection. Immunology 93:431-436.

Ingram, D. G., and W. R. Mitchell. 1970. Conglutinin levels in dairy cattle: Changes associated with parturition. Am. J. Vet. Res. 31:487-492.

Ingram, D. G., and W. R. Mitchell. 1971. Conglutinin levels in dairy cattle: Seasonal fluctuations. Am. J. Vet. Res. 32:23-28. 
Ingvartsen, K. L., R. J. Dewhurst, and N. C. Friggens. 2003. On the relationship between lactational performance and health: Is it yield or metabolic imbalance that cause production diseases in dairy cattle? A position paper. Livest. Prod. Sci. 83:277-308.

Ingvartsen, K. L., and N. C. Friggens. 2005. To what extent do variabilities in hormones, metabolites and energy intake explain variability in milk yield? Domest. Anim. Endocrinol. 29:294-304.

Kehrli, M. E., Jr., B. J. Nonnecke, and J. A. Roth. 1989. Alterations in bovine neutrophil function during the periparturient period. Am. J. Vet. Res. 50:207-214.

Kehrli, M. E., K. A. Weigel, A. E. Freeman, J. R. Thurston, and D. H. Kelley. 1991. Bovine sire effects on daughters in vitro blood neutrophil functions, lymphocyte blastogenesis, serum complement and conglutinin levels. Vet. Immunol. Immunopathol. 27:303-319.

Kommisrud, E., O. Osteras, and T. Vatn. 2005. Blood selenium associated with health and fertility in Norwegian dairy herds. Acta Vet. Scand. 46:229-240.

Kristensen, N. B., S. G. Pierzynowski, and A. Danfaer. 2000. Net portal appearance of volatile fatty acids in sheep intraruminally infused with mixtures of acetate, propionate, isobutyrate, butyrate, and valerate. J. Anim. Sci. 78:1372-1379.

Krogh-Meibom, T., U. Holmskov, P. Lovendahl, and K. L. Ingvartsen. 2004a. A time-resolved immunofluorometric assay for quantification of collectin-43. J. Immunol. Methods 295:161-167.

Krogh-Meibom, T., U. Holmskov, P. Lovendahl, N. I. Nielsen, and K. L. Ingvartsen. 2004b. A time-resolved immunofluorometric assay for quantification of the bovine collectin conglutinin. J. Immunol. Methods 286:87-96.

Littell, R. C., G. A. Milliken, W. W. Stroup, and R. D. Wolfinger. 1996. SAS system for mixed models. SAS Institute Inc., Cary, NC.

Løvendahl, P., and H. M. Purup. 2002. Technical note: Time-resolved fluoro-immunometric assay for intact insulin in livestock species. J. Anim. Sci. 80:191-195.

Mallard, B. A., J. C. Dekkers, M. J. Ireland, K. E. Leslie, S. Sharif, C. L. Vankampen, L. Wagter, and B. N. Wilkie. 1998. Alteration in immune responsiveness during the peripartum period and its ramification on dairy cow and calf health. J. Dairy Sci. 81:585595.

Mashek, D. G., K. L. Ingvartsen, J. B. Andersen, M. Vestergaard, and T. Larsen. 2001. Effects of a four-day hyperinsulinemic-euglycemic clamp in early and mid-lactation dairy cows on plasma concentrations of metabolites, hormones, and binding proteins. Domest. Anim. Endocrinol. 21:169-185.

Meglia, G. E., S. K. Jensen, C. Lauridsen, and W. K. Persson. 2006. Alpha-tocopherol concentration and stereoisomer composition in plasma and milk from dairy cows fed natural or synthetic vitamin E around calving. J. Dairy Res. 73:227-234.

Miltenburg, J. D., D. deLange, A. P. P. Crauwels, J. H. Bongers, M. J. M. Tielen, Y. H. Schukken, and A. R. W. Elbers. 1996. Incidence of clinical mastitis in a random sample of dairy herds in the southern Netherlands. Vet. Rec. 139:204-207.

Murata, H., N. Shimada, and M. Yoshioka. 2004. Current research on acute phase proteins in veterinary diagnosis: An overview. Vet. J. 168:28-40.

Nyman, A. K., T. Ekman, U. Emanuelson, A. H. Gustafsson, K. Holtenius, K. P. Waller, and C. H. Sandgren. 2007. Risk factors associated with the incidence of veterinary-treated clinical mastitis in Swedish dairy herds with a high milk yield and a low prevalence of subclinical mastitis. Prev. Vet. Med. 78:142-160.

Odensten, M. O., B. Berglund, W. K. Persson, and K. Holtenius. 2007. Metabolism and udder health at dry-off in cows of different breeds and production levels. J. Dairy Sci. 90:1417-1428.
Odensten, M. O., Y. Chilliard, and K. Holtenius. 2005. Effects of two different feeding strategies during dry-off on metabolism in highyielding dairy cows. J. Dairy Sci. 88:2072-2082.

Ohtsuka, H., M. Kohiruimaki, T. Hayashi, K. Katsuda, K. Matsuda, M. Masui, R. Abe, and S. Kawamura. 2006. Relationship between leukocyte population and nutritive conditions in dairy herds with frequently appearing mastitis. J. Vet. Med. Sci. 68:113-118.

Persson Waller, K., S. C. Hallen, U. Emanuelson, and S. K. Jensen. 2007. Supplementation of RRR-alpha-tocopheryl acetate to periparturient dairy cows in commercial herds with high mastitis incidence. J. Dairy Sci. 90:3640-3646.

Puls, R. 1994. Mineral levels in animal health: Diagnostic data. Sherpa International, Clearbrook, Canada.

Rastani, R. R., S. M. Andrew, S. A. Zinn, and C. J. Sniffen. 2001. Body composition and estimated tissue energy balance in Jersey and Holstein cows during early lactation. J. Dairy Sci. 84:1201-1209.

Reist, M., D. Erdin, D. von Euw, K. Tschuemperlin, H. Leuenberger, Y. Chilliard, H. M. Hammon, C. Morel, C. Philipona, Y. Zbinden, N. Kuenzi, and J. W. Blum. 2002. Estimation of energy balance at the individual and herd level using blood and milk traits in high-yielding dairy cows. J. Dairy Sci. 85:3314-3327.

Rezamand, P., T. A. Hoagland, K. M. Moyes, L. K. Silbart, and S. M. Andrew. 2007. Energy status, lipid-soluble vitamins, and acute phase proteins in periparturient Holstein and Jersey dairy cows with or without subclinical mastitis. J. Dairy Sci. 90:5097-5107.

Smith, K. L., J. H. Harrison, D. D. Hancock, D. A. Todhunter, and H. R. Conrad. 1984. Effect of vitamin E and selenium supplementation on incidence of clinical mastitis and duration of clinical symptoms. J. Dairy Sci. 67:1293-1300.

Sordillo, L. M., M. J. Redmond, M. Campos, L. Warren, and L. A. Babiuk. 1991. Cytokine activity in bovine mammary gland secretions during the periparturient period. Can. J. Vet. Res. 55:298-301.

Suriyasathaporn, W., C. Heuer, E. N. Noordhuizen-Stassen, and Y. H. Schukken. 2000. Hyperketonemia and the impairment of udder defense: A review. Vet. Res. 31:397-412.

Swedish Dairy Association. 2006. Animal health 2005/2006: Annual report from the animal health section. Swedish Dairy Association, Eskilstuna, Sweden.

van Dam, B. P., P. C. Bartlett, J. H. Kirk, and E. C. Mather. 1988. The effect of age at calving on reproduction, milk production and disease incidence in the first lactation of dairy heifers. Theriogenology 30:583-591.

van Knegsel, A. T. M., H. van den Brand, J. Dijkstra, S. Tamminga, and B. Kemp. 2005. Effect of dietary energy source on energy balance, production, metabolic disorders and reproduction in lactating dairy cattle. Reprod. Nutr. Dev. 45:665-688.

Waage, S., S. Sviland, and S. A. Odegaard. 1998. Identification of risk factors for clinical mastitis in dairy heifers. J. Dairy Sci. $81: 1275-1284$.

Wang, C., J. X. Liu, Z. P. Yuan, Y. M. Wu, S. W. Zhai, and H. W. Ye. 2007. Effect of level of metabolizable protein on milk production and nitrogen utilization in lactating dairy cows. J. Dairy Sci. 90:2960-2965.

Wathes, D. C., Z. Cheng, N. Bourne, V. J. Taylor, M. P. Coffey, and S. Brotherstone. 2007. Differences between primiparous and multiparous dairy cows in the inter-relationships between metabolic traits, milk yield and body condition score in the periparturient period. Domest. Anim. Endocrinol. 33:203-225.

Weiss, W. P., J. S. Hogan, K. L. Smith, and K. H. Hoblet. 1990. Relationships among selenium, vitamin E, and mammary gland health in commercial dairy herds. J. Dairy Sci. 73:381-390. 